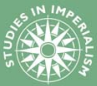

\title{
SERVING THE \\ EMPIRE IN THE \\ GREAT WAR
}

The Cypriot Mule Corps, imperial loyalty and silenced memory

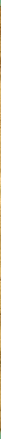

AAndDeRosk KOrgaVA R 197845A6103680 m manchesterhive.com at 04/26/2023 12:37:07PM via free access 


\section{IMPERIALISM}

General editor: Andrew S. Thompson

Founding editor: John M. MacKenzie

When the 'Studies in Imperialism' series was founded more than twenty-five years ago, emphasis was laid upon the conviction that 'imperialism as a cultural phenomenon had as significant an effect on the dominant as on the subordinate societies'. With well over a hundred titles now published, this remains the prime concern of the series. Cross-disciplinary work has indeed appeared covering the full spectrum of cultural phenomena, as well as examining aspects of gender and sex, frontiers and law, science and the environment, language and literature, migration and patriotic societies, and much else. Moreover, the series has always wished to present comparative work on European and American imperialism, and particularly welcomes the submission of books in these areas. The fascination with imperialism, in all its aspects, shows no sign of abating, and this series will continue to lead the way in encouraging the widest possible range of studies in the field. 'Studies in Imperialism' is fully organic in its development, always seeking to be at the cutting edge, responding to the latest interests of scholars and the needs of this ever-expanding area of scholarship.

\section{Serving the empire in the Great War}

\section{MANCHESTER} 1824

Manchester University Press 


\section{SELECTED TITLES AVAILABLE IN THE SERIES}

\section{IMPERIAL EXPECTATIONS AND REALITIES}

El Dorados, utopias and dystopias ed. Andrekos Varnava

BRITISH IMPERIALISM IN CYPRUS, 1878-1915

The inconsequential possession

Andrekos Varnava

\section{BEASTLY ENCOUNTERS OF THE RAJ}

Livelihoods, livestock and veterinary health in North India, 1790-1920 Saurabh Mishra

\section{ENGINES FOR EMPIRE}

The Victorian army and its use of railways

Edward Spiers

THE CULTURAL CONSTRUCTION OF THE BRITISH WORLD

ed. Barry Crosbie and Mark Hampton 


\section{Serving the empire in the Great War}

THE CYPRIOT MULE CORPS, IMPERIAL LOYALTY AND SILENCED MEMORY

Andrekos Varnava

MANCHESTER

UNIVERSITY PRESS 
Copyright (C) Andrekos Varnava 2017

The right of Andrekos Varnava to be identified as the author of this work has been asserted by him in accordance with the Copyright, Designs and Patents Act 1988.

Published by MANCHESTER UNIVERSITY PRESS

ALTRINCHAM STREET, MANCHESTER M1 7JA

www.manchesteruniversitypress.co.uk

British Library Cataloguing-in-Publication Data

A catalogue record for this book is available from the British Library

Library of Congress Cataloging-in-Publication Data applied for

ISBN 9781526103673 hardback

First published 2017

The publisher has no responsibility for the persistence or accuracy of URLs for any external or third-party internet websites referred to in this book, and does not guarantee that any content on such websites is, or will remain, accurate or appropriate.

Typeset by

Servis Filmsetting Ltd, Stockport, Cheshire 